\title{
Time to metamorphosis of blue crab Callinectes sapidus megalopae: effects of benthic macroalgae
}

\author{
Robert D. Brumbaugh*, John R. McConaugha \\ Department of Oceanography, Old Dominion University, Norfolk, Virginia 23529-0276, USA
}

\begin{abstract}
There is growing evidence that postlarvae (megalopae) of the blue crab Callinectes sapidus can slow the progression through the molt cycle while in offshore nursery grounds, and delay metamorphosis until reinvasion of coastal habitat occurs. However, the cues that trigger metamorphosis of megalopae are not well known. This study tested the hypothesis that the time to metamorphosis (TTM) from the postlarval megalops stage to the first crab stage is shortened in the presence of 2 potential macroalgal settlement substrates, Ulva lactuca (Chlorophyta), and Gracilaria spp. (Rhodophyta) Megalopae and test water were collected from 3 locations foffshore, at a coastal inlet, and inside a coastal lagoon) and tested in a completely crossed factorial experiment with algal type and location as main effects. TTM was longest in offshore treatments (mean TTM $4.72 \mathrm{~d}$ ) and similar in the inshore treatments (mean inlet TTM $2.73 \mathrm{~d}$, lagoon TTM $2.51 \mathrm{~d}$ ). TTM of offshore megalopae was reduced in the presence of Ulva lactuca, but macroalgae had little effect on the inshore treatment groups. The effect of algal cues may be masked once megalopae have initiated premolt prior to invading coastal lagoons.
\end{abstract}

KEY WORDS: Blue crab Callinectes sapidus Metamorphosis Macroalgae

\section{INTRODUCTION}

The recruitment of marine fish and invertebrate larvae and postlarvae into coastal and estuarine habitats is considered to be a potential regulator of marine populations (Roughgarden et al. 1988, Possingham \& Roughgarden 1990). Part of the recruitment process for benthic or demersal organisms is the selection of favorable habitat for settlement and metamorphosis to the juvenile stage. The potential cues that allow settling larvae or postlarvae to identify a favorable habitat have been investigated for several taxa, including gastropods (Morse \& Morse 1984), polychaetes (Williams 1964, Kirchman et al. 1982, Butman et al. 1988), and bivalves (Chevolot et al. 1991, Kitt \& Coon 1992, Harvey et al. 1993). However, few studies have examined how cues associated with settlement habitat affect the time required for metamorphosis in crustaceans (Christy 1989, Butler \& Herrnkind 1991, O'Conner 1991)

•E-mail: rob@ocean odu.edu
Larvae (zoeae) of the blue crab are exported from estuaries and coastal embayments to adjacent shelf waters (Sandifer 1975, McConaugha et al. 1983). After molting through 7 or 8 zoeal stages, the larvae molt into a postlarval (megalops) stage (Costlow \& Bookhout 1959) that reinvades coastal habitats. The exact mechanism for this reinvasion is not known, but may be the result of a combination of changes in postlarval behavior and physical transport by wind-driven and tidal currents (Sulkin et al. 1980, Johnson et al. 1984, Brookins \& Epifanio 1985, Goodrich et al. 1989, Forward \& Rittschof 1994, Olmi 1994). In Chesapeake Bay, USA, newly recruited blue crab megalopae appear to settle preferentially into seagrass (Zostera marina) beds (Orth \& van Montfrans 1987). In the back-barrier lagoons along the outer coast of Virginia, USA, seagrasses are largely absent, and megalopae must settle on alternative substrates such as benthic macroalgae.

It has been hypothesized that blue crab megalopae can delay metamorphosis prior to reinvasion of estuarine environments (McConaugha 1988, Wolcott \& De Vries 1994). Delaying metamorphosis prior to reinva- 


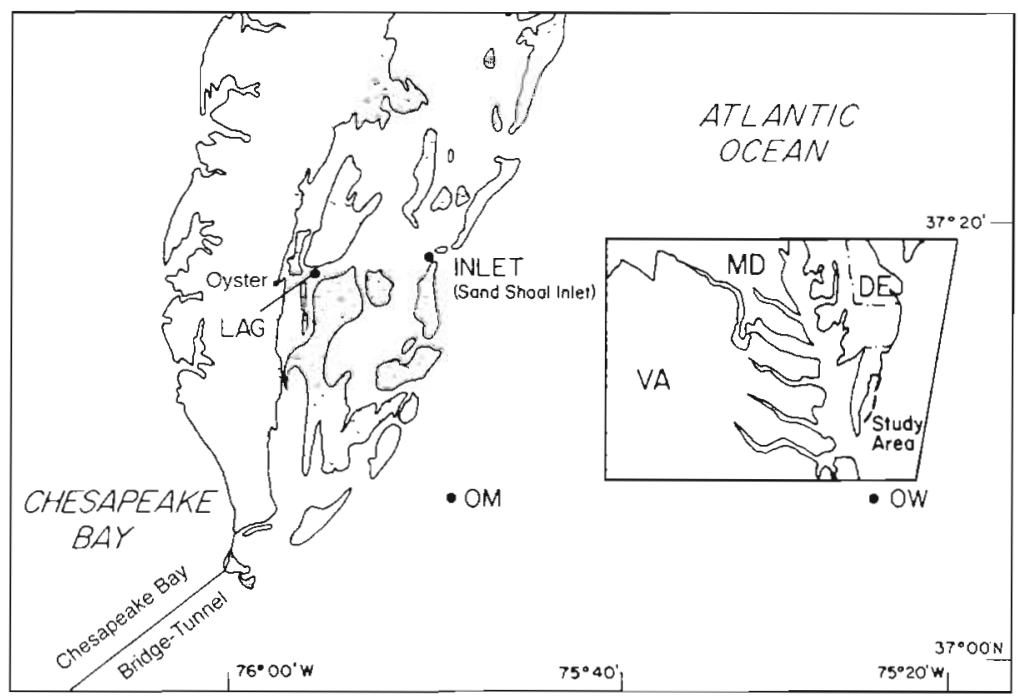

Fig. 1. Locations along the outer coast of Virginia, USA, of megalopae and water collection for the 4 experiments. OW: offshore water; OM: offshore megalopae; INLET: water and megalopae from Sand Shoal Inlet; LAG: water and megalopae for both lagoon experiments sion of an estuary would prevent settlement offshore, thus decreasing early mortality (Pechenik 1990). There is growing evidence that blue crab megalopae recognize and respond to cues associated with the nearshore environment. These cues alter behavioral patterns and accelerate metamorphosis to the first crab stage (Forward \& Rittschof 1994, Forward et al. 1994).

In this study, we examined the effects of 2 species of benthic macroalgae, Ulva lactuca and Gracilaria spp. on the time to metamorphosis (TTM) of blue crab megalopae collected offshore, at a coastal inlet, and inside a coastal lagoon along Virginia's outer coast. These macroalgae are the dominant form of submerged aquatic vegetation (SAV) in Virginia's coastal lagoons, and megalopae readily settle into clumps of both species (Brumbaugh unpubl. data). Testing megalopae from different locations allowed us to examine the in situ effects of these macroalgae on offshore megalopae prior to reinvasion, and on megalopae within a coastal embayment where settlement and metamorphosis to the first benthic crab stage occurs.

\section{METHODS AND MATERIALS}

A total of 4 experiments were conducted using blue crab megalopae and water collected at 3 locations during July and August (1994) (Fig. 1). The first experiment was conducted with megalopae collected $10.75 \mathrm{~m}$ bongo net, $333 \mu \mathrm{m}$ mesh) from an offshore site approximately $7.5 \mathrm{~km}$ east of Cape Charles, Virginia $\left(37^{\circ} 7.4^{\prime}\right.$ $\mathrm{N}, 75^{\circ} 50.0^{\prime} \mathrm{W}$ ). This site is north and east of the outflow from Chesapeake Bay. Test water for this experiment was obtained at a second station $37 \mathrm{~km}$ east of the megalopa collection site $\left(37^{\circ} 7.4^{\prime} \mathrm{N}, 75^{\circ} 25.7^{\prime} \mathrm{W}\right)$ and was glass fiber filtered (GFF) prior to use (nominal pore size $1 \mu \mathrm{m}$ ). The salinity of the offshore test water was 32 ppt (Seabird CTD). Waters on the inner continental shelf of the mid-Atlantic Bight (MAB) are generally low salinity, averaging 32.5 ppt (Ingham et al. 1982), resulting from discharge from several major estuaries in this region (Norcross \& Harrison 1967).

Three additional experiments were conducted at inshore stations. One experiment was conducted with megalopae and water collected at Sand Shoal Inlet, Virginia (hereafter referred to as 'inlet'), approximately $18 \mathrm{~km}$ north of Chesapeake Bay mouth. The other 2 experiments tested megalopae collected at a lagoonal site $10 \mathrm{~km}$ inshore from the inlet site. Water from the inlet and one of the lagoon experiments was glass fiber filtered prior to use. The unfiltered lagoon experiment was conducted separately using megalopae and unfiltered water from the lagoon site. Since the unfiltered water treatment is not crossed with the other sites, these data were not included in the statistical analysis. The salinity at all inshore sites was $32 \mathrm{ppt}$ (AO refractometer). The lagoonal system receives almost no freshwater input and is directly influenced by coastal water entering and exiting through tidal inlets.

The general experimental procedure was the same for all 4 experiments. After collection, megalopae were quickly pipetted from the rest of the plankton sample. Megalopae were held in compartmentalized tackle boxes containing approximately $50 \mathrm{ml}$ of test water per compartment (1 megalopa per compartment). Megalopae were randomly assigned to 1 of 3 treatment groups: Ulva lactuca (U), Gracilaria spp. (G), or no algae (NA). For the $U$ and $G$ treatments, a small sample of macroalgae was placed in the appropriate compartments. Each sample of U. lactuca was approximately $2.5 \times 2.5 \mathrm{~cm}$, and covered approximately half the bot- 
Table 1. Description of epidermal changes used to classify megalopal molt stages (modified from Hatfield 1983, Metcalf \& Lipcius 1992)

\begin{tabular}{|c|c|c|}
\hline $\begin{array}{l}\text { Molting } \\
\text { activity }\end{array}$ & $\begin{array}{l}\text { Molt } \\
\text { stage }\end{array}$ & Observations used \\
\hline Postmolt & $A-B$ & No epidermal retraction \\
\hline Intermolt & $\mathrm{C}$ & No epidermal retraction \\
\hline \multirow[t]{4}{*}{ Premolt } & Do & $\begin{array}{l}\text { Epidermis begins to retract } \\
\text { from cuticle; retraction } \\
<5 \% \text { within rostral and } \\
\text { ventral spines }\end{array}$ \\
\hline & $\mathrm{DO}^{\prime}$ & $\begin{array}{l}\text { Moderate retraction of } \\
\text { epidermis within spines (>50\%) }\end{array}$ \\
\hline & D1 & $\begin{array}{l}\text { Epidermis fully retracted } \\
\text { within spines; some evidence } \\
\text { of new setae in dactyl segment } \\
\text { of } 5 \text { th leg; epidermal } \\
\text { iretraction apparent in } \\
\text { maxilliped }\end{array}$ \\
\hline & $\mathrm{D} 1^{\prime}$ & $\begin{array}{l}\text { New setae completely formed in } \\
\text { dactyl segment of } 5 \text { th leg; } \\
\text { invagination of new setae in } \\
\text { maxilliped }\end{array}$ \\
\hline Ecdysis & $E$ & Molting occurs \\
\hline
\end{tabular}

tom of the individual compartment. A section of Gracilaria approximately $4 \mathrm{~cm}$ in length was added to the appropriate compartments. Gracilaria is a branching red alga, and each experimental segment consisted of several smaller branches which filled approximately one-third to one-half of the compartment. Megalopae in the NA treatment were held in compartments containing test water without macroalgae or any substrate other than the container itself.

Megalopae were molt staged at the start of the experiment using a method modified from Hatfield (1983) and Metcalf \& Lipcius (1992) (Table 1). Nearly all megalopae in the offshore collection were in intermolt (molt stage C; see Stevenson 1985, and references therein), while all megalopae collected inshore (inlet and lagoon) were in premolt (molt stage Do to D1) (Fig. 2). To reduce the variability within the various treatment groups, only megalopae in the same molt stage were used in the analysis (i.e. only those in molt stage $\mathrm{C}$ offshore, molt stage D0 for all others). Experiments were carried out in the dark to minimize light effects and water was changed approximately every $36 \mathrm{~h}$. This was done primarily because there were no facilities aboard the research vessel for adequately maintaining even lighting conditions throughout the offshore experiment. Megalopae were not fed during the experiment. Observations were made approximately every $8 \mathrm{~h}$ to check for megalopae that had molted. Exposure to light was kept to a minimum during observations.
The offshore experiment was started during a research cruise on the NOAA ship 'Ferrel' (12 July to 15 July 1994). Since not all megalopae had molted by the end of the cruise, the experiment was completed shoreside. The compartmentalized trays were transported from the ship to the lab at Old Dominion University (ODU), Norfolk, Virginia, in an insulated cooler (transport time approx. $15 \mathrm{~min}$ ). There was no change in temperature during transport or after arrival at ODU $\left(22.5 \pm 1.0^{\circ} \mathrm{C}\right.$ throughout experiment). Experiments with megalopae collected at the inlet and inner lagoon were conducted at the ODU Barrier Island Research Station, in Oyster, Virginia (August 29 to September 19 , 1994). Temperatures varied only slightly during these experiments as well [inlet $24.4 \pm 0.8^{\circ} \mathrm{C}_{i}$ lagoon (filtered water) $23.3 \pm 1.5^{\circ} \mathrm{C}$; lagoon (unfiltered water) $\left.24.7 \pm 2.0^{\circ} \mathrm{C}\right]$

Individual experiments were conducted with 13 to 29 megalopae per treatment group and mortality was negligible in all experiments. The mean TTM was calculated for each treatment group, and data were analyzed as a $(3 \times 3) 2$-factor ANOVA using the GLM procedure in SAS (SAS Institute, Cary, NC, USA). Data were rank-transformed prior to statistical analysis (Conover \& Iman 1981) to eliminate problems with non-normality. Rank transformation stabilizes the distribution of non-normal data and allows the data to be analyzed using ANOVA techniques (Conover \& Iman 1981, Potvin \& Roff 1993)

\section{RESULTS}

Time to metamorphosis was longest in the offshore treatments, with TTM offshore ranging from 3.82 to $5.24 \mathrm{~d}$ (Table 2). There was a marked decrease in

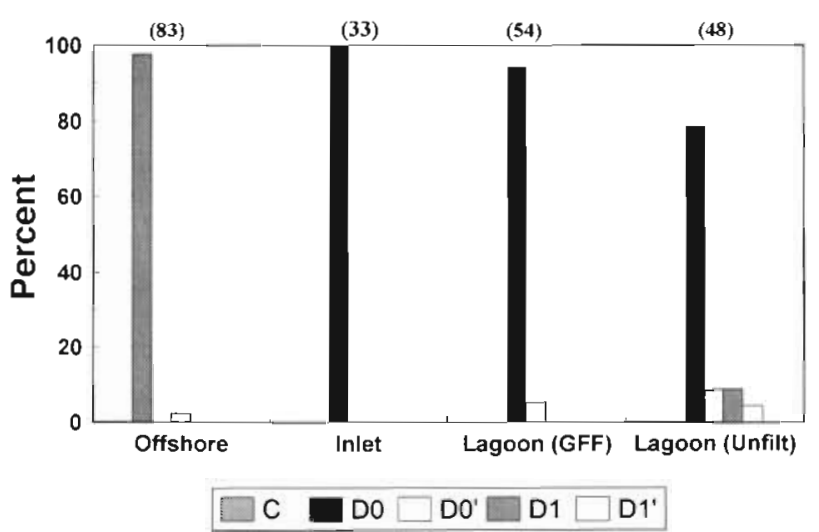

Fig. 2. Callinectes sapidus. Molt stage of megalopae from each experiment. Numbers at the top of the graph indicate sample sizes at each location. GFF: GFF filtered water ${ }_{i}$ Unfilt: unfiltered water 
TTM from offshore to inshore, with inlet and lagoon megalopae molting on average 42 to $47 \%$ faster than offshore megalopae (filtered water experiments; Table 2). This difference illustrates the effect of the change in physiological state between offshore megalopae, which were in intermolt, and inshore megalopae which were in premolt. The mean TTM was lowest in the unfiltered lagoon water (unweighted mean of 3 treatments $=1.95 \mathrm{~d} ; \mathrm{SD}=0.22 ; \mathrm{n}=51$; Table 2).

In the offshore experiment, Ulva lactuca appeared to induce metamorphosis more quickly $(3.82 \mathrm{~d}$; $\mathrm{SD}=1.24$; $\mathrm{n}=26)$ than $\mathrm{G}(5.03 \mathrm{~d}$; $\mathrm{SD}=2.02 ; \mathrm{n}=29)$ or the NA treatment (5.24 $\left.\mathrm{d}_{i} \mathrm{SD}=1.54 ; \mathrm{n}=29\right)$. However, differences in TTM among treatments were minor at the inshore sites (Fig. 3). There was significant interaction between the main effects of location and algal type ( $\mathrm{p}=$ 0.0221 ; Table 3 ), which prevented statistical analysis of these individual effects.

\section{DISCUSSION}

The apparent difference between the $\mathrm{U}$ treatment and the G and NA treatments offshore (Fig. 3) suggests that while megalopae are offshore (i.e. in intermolt), they are more responsive to cues received from coastal environments. Therefore, the megalopae may have been responding to the presence of Ulva lactuca in the offshore experiment, although the exact signal associated with $U$. lactuca is not known. Gracilaria spp. did not appear to affect TTM, which suggests that not all algae are equally effective as cues. This may also indi-

Table 2. Mean time (days) to metamorphosis ( $\pm 1 \mathrm{SD}$ ). Three locations were examined: offshore, inlet and lagoon, with 3 algal treatments: Ulva lactuca (U), Gracilaria spp. (G), and no algae (NA). Two separate experiments were conducted at the lagoon site, one with filtered water $(F)$ and one with unfiltered water (UF). The unfiltered water data are included for comparison but were not included in the statistical analysis. The unweighted mean TTM is also included for each location

\begin{tabular}{|c|c|c|c|c|}
\hline & \multicolumn{3}{|c|}{ Algal treatment } & Mean \\
\hline Offshore & $\begin{array}{c}3.82(1.24) \\
\mathrm{n}=26\end{array}$ & $\begin{array}{c}5.03(2.02) \\
\mathrm{n}=29\end{array}$ & $\begin{array}{c}5.24(1.54) \\
\mathrm{n}=26\end{array}$ & $4.72(0.72$ \\
\hline Inlet & $\begin{array}{c}2.84(0.59) \\
n=12\end{array}$ & $\begin{array}{c}2.56(0.38) \\
n=10\end{array}$ & $\begin{array}{c}2.78(0.69) \\
n=11\end{array}$ & $2.72(0.15)$ \\
\hline Lagoon (F) & $\begin{array}{c}2.50(0.31) \\
n=18\end{array}$ & $\begin{array}{c}2.41(0.29) \\
n=1.7\end{array}$ & $\begin{array}{c}2.61(0.23) \\
n=16\end{array}$ & $2.51(0.10)$ \\
\hline Lagoon (UF) & $\begin{array}{c}2.21(0.45) \\
\mathrm{n}=12\end{array}$ & $\begin{array}{c}1.81(0.22) \\
n=11\end{array}$ & $\begin{array}{c}1.84(0.67) \\
n=14\end{array}$ & $1.95(0.22)$ \\
\hline
\end{tabular}

cate that blue crab megalopae do not respond to tactile cues. However, as Wolcott \& De Vries (1994) pointed out, the collection process itself and the confines of experimental containers may serve as underlying tactile cues.

The $22 \%$ difference in mean TTM $(0.554 \mathrm{~d})$ between filtered and unfiltered lagoon water may represent the natural variance in physiological state of the megalopae as they invade the lagoon, although the inshore experiments were standardized somewhat by comparing only those megalopae in the same molt stage (molt stage $\mathrm{D} 0$; initiation of premolt). The temperature difference between experimental conditions was small $\left(24.6 \pm 2.0^{\circ} \mathrm{C}\right.$ in unfiltered lagoon water versus $23.3 \pm$ $1.5^{\circ} \mathrm{C}$ in filtered lagoon water). Whether this difference between mean temperatures accounts for the lower TTM in the unfiltered treatments is not known. An alternative explanation is that megalopae in the unfiltered lagoon water responded to a particulate cue that was removed by filtration in the filtered lagoon water experiment.

Of the offshore treatments, only the NA treatment (5.24 d; $\mathrm{SD}=1.567_{i} \mathrm{n}=29$ ) is significantly different [Student's 1 -tailed $t$-test, $\alpha$ adjusted for 3 comparisons (i.e. $0.05 / 3=0.016$ ); $p<0.01$ ] from the TTM reported by Forward et al. (1994) for megalopae exposed to offshore water $(4.37 \mathrm{~d} ; \mathrm{SD}=0.94 ; \mathrm{n}=9$ ). The megalopae in their experiments had been collected within a coastal estuary and held in lagoon/estuarine water (salinity 35 ppt) prior to immersion in the offshore test water. Megalopae for our offshore experiment were collected outside the influence of Chesapeake Bay and, presumably, have not received any prior estuarine cues, which may explain this difference. Clearly, other differences between these 2 studies exist. However, their study demonstrated that megalopae could delay metamorphosis once estuarine cues had been removed by placing them in offshore water, which supports the observed difference in TTM. 


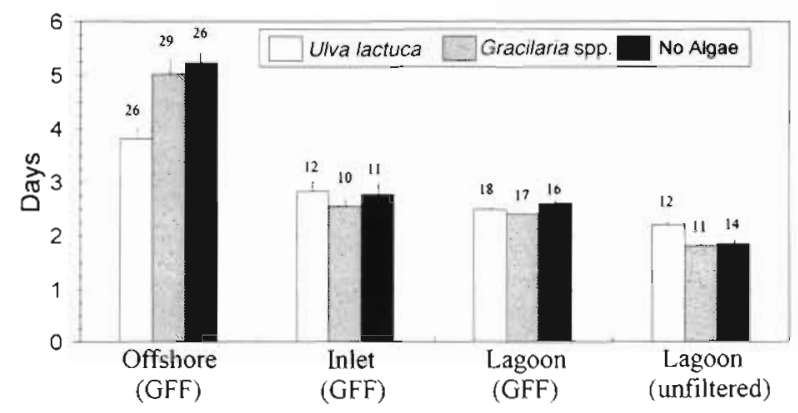

Fig. 3. Mean TTM of megalopae in the presence of macroalgae. Error bars are $1 \mathrm{SE}$ of the mean. Numbers over the columns are sample sizes for each treatment group

Forward et al. (1994) also showed that metamorphosis of blue crab megalopae was accelerated in the presence of eelgrass Zostera marina in estuarine water ( $2.88 \mathrm{~d} ; \mathrm{SD}=0.22 ; \mathrm{n}=6$; salinity $35 \mathrm{ppt}$ ). This value is similar to all of the filtered inshore treatment groups in our study, including the NA treatments, and significantly greater than all of the unfiltered treatment groups (Student's 1 -tailed t-test, $\alpha$ adjusted for 6 comparisons; $p<0.001$ ). This may be a further indication that megalopae in this study responded to some particulate fraction in the water column, as the test water in their experiments had also been filtered ( $5 \mu \mathrm{m})$ prior to use (Forward et al. 1994).

Because salinity is high ( $>30$ ppt) in the coastal lagoons along Virginia's outer coast, our study did not consider the synergistic effect that salinity and algal substrate may have on TTM. The effect of macroalgae on TTM may be more pronounced when tested in concert with other estuarine variables, such as decreased salinity.

Many larvae are thought to enter a 'competency' phase prior to initiating settlement and metamorphosis (Burke 1983, and references therein). However, competency is not well defined for highly motile taxa such as decapods, which do not permanently attach themselves to the substrate upon metamorphosis. The thigmotactic nature, or tendency to cling to objects, of blue crab postlarvae was clearly evident in the megalopae collected offshore, as they were observed to readily settle on pieces of macroalgae offered in the experimental compartments. The longer time required for metamorphosis and the intermolt status of the offshore megalopae suggests that settlement ability alone is probably not an appropriate measure of competency for blue crab megalopae. Instead, the initiation of premolt, which presumably occurs during or shortly before reinvasion of coastal or estuarine environments, is probably the best analog for competency in blue crab postlarvae. After that point, other cues, such as those associated with specific settlement substrates, may have less of an effect on TTM and be more difficult to discern experimentally.

Megalopae collected in the inlet and coastal lagoon were all in premolt and showed a marked decrease in TTM and reduced response to algal substrates compared to offshore megalopae (Fig. 3). This supports the hypothesis that megalopae receive estuarine cues to accelerate metamorphosis as they near the coast (Forward et al. 1994). Tactile stimulation due to the presence of algae did not appear to affect TTM, as the megalopae in the offshore $G$ treatment were not different than the NA treatment.

Metamorphic cues associated with Ulva lactuca may be masked by the presence of other estuarine cues $(<1 \mu \mathrm{m})$ within the lagoons after megalopae have entered premolt. Therefore, the importance of macroalgae to megalopae that have entered the lagoon may be in reducing predation (Wilson et al. 1990, Sogard \& Able 1991) or for food production rather than as a cue for metamorphosis. The presence of other cues in unfiltered lagoon water (particulates $>1 \mu \mathrm{m}$ ) may enhance molting activity in the lagoons.

Acknowledgements. This study was supported by the Department of Oceanography, Old Dominion University (ODU), and by a grant from Earthwatch/The Center for Field Research to R.B. and J.M. Five Earthwatch volunteers aided in the collection and sorting of megalopae for the inshore experiments. Dr Jerry Miller, ODU, graciously invited R.B. to participate on a cruise aboard the NOAA ship 'Ferrel', which made the offshore component of this work possible. Dr Mark Butler IV, ODU, provided valuable statistical advice. Lisa Drake, ODU, monitored the offshore experiment to completion after it was moved to ODU and offered comments on various drafts of the manuscript. The comments of Dr Richard Forward, Jr and 2 anonymous reviewers greatly improved an earlier version of this manuscript.

\section{LITERATURE CITED}

Brookins KG, Epifanio CE (1985) Abundance of brachyuran larvae in a small coastal inlet over six consecutive tidal cycles. Estuaries 8(1):60-67

Burke RD (1.983) The induction of metamorphosis of marine invertebrate larvae: stimulus and response. Can J Zool 61:1701-1719

Butler MJ IV, Herrnkind WF (1991) Effect of benthic microhabitat cues on the metamorphosis of pueruli of the spiny lobster Panulirus argus. J crust Biol 11(1):23-28

Butman CA, Grassle JP, Webb CM (1988) Substrate choices made by marine larvae settling in still water and in a flume flow. Nature 333:771-773

Chevolot L, Cochard JC, Yvin JC (1991) Chemical induction of larval metamorphosis of Pecten maximus with a note on the nature of naturally occurring triggering substances. Mar Ecol Prog Ser 74:83-89

Christy JH (1989) Rapid development of megalopae of the fiddler crab Uca pugilator reared over sediment: implications for models of larval recruitment. Mar Ecol Prog Ser 57:259-265 
Conover WJ, Iman RL (1981) Rank transformations as a bridge between parametric and nonparametric statistics. Am Statist 35(3): 124-129

Costlow JD, Bookhout CG (1959) The larval development of Callinectes sapidus Rathbun reared in the laboratory. Biol Bull mar. biol Lab, Woods Hole 118:203-214

Forward RB Jr, Frankel DAZ, Rittschof D (1994) Molting of megalopae from the blue crab Callinectes sapidus: effects of offshore and estuarine cues. Mar Ecol Prog Ser 113: $55-59$

Forward RB Jr, Rittschof D (1994) Photoresponses of crab megalopae in offshore and estuarine waters: implications for transport. J exp mar Biol Ecol 182:183-192

Goodrich DM, van Montfrans J, Orth RJ (1989) Blue crab megalopal influx to Chesapeake Bay: evidence for a winddriven mechanism. Estuar coast Shelf Sci 29:247-260

Harvey M, Bourget E, Miron G (1993) Settlement of Iceland scallop Chlamys islandica spat in response to hydroids and filamentous red algae: field observations and laboratory experiments. Mar Ecol Prog Ser 99:283-292

Hatfield SE (1983) Intermolt staging and distribution of dungeness crab, Cancer magister, megalopae. Calif Dep Fish Game Bull 172:85-96

Ingham MC et al. (1982) Summary of the physical oceanographic processes and features pertinent to pollution distribution in the coastal and offshore waters of the northeastern United States, Virginia to Maine. NOAA Tech Mem NMFS-F/NEC-17

Johnson DR, Hester BS, McConaugha JR (1984) Studies of a wind mechanism influencing the recruitment of blue crabs in the middle Atlantic Bight. Cont Shelf Res 3:425- 437

Kirchman D, Graham S, Reish D, Mitchell R (1982) Bacteria induce settlement and metamorphosis of Janua (Drexispira) brasiliensis Grube (Polychaeta: spirorbidae) J exp mar Biol Ecol 56:153-163

Kıtt WK, Coon SL (1992) Evidence for ammonia as a natural cue for recruitment of oyster larvae to oyster beds in a Georgia salt marsh. Biol Bull 182:401-408

McConaugha JR (1988) Export and reinvasion of larvae as regulators of estuarine decapod populations. Am Fish Soc Symp 3:90-103

McConaugha JR, Johnson DF, Provenzano AJ, Maris RC (1983) Seasonal distribution of larvae of Callinectes sapidus (Crustacea: Decapoda) in the waters adjacent to Chesapeake Bay. J crust Biol 3(4):582-591

Metcalf KS, Lipcius RN (1992) Relationship of habitat and spatial scale with physiological state and settlement of blue crab postlarvae in Chesapeake Bay. Mar Ecol Prog Ser 82:143-150

Morse ANC, Morse DE (1984) Recruitment and metamorphosis of Haliotis larvae are induced by molecules uniquely available at the surfaces of crustose red algae. J exp mar Biol Ecol 75:191-215

This article was presented by K. L. Heck Jr (Senior Editorial Advisor), Dauphin Island, Alabama, USA
Norcross JJ, Harrison W (1967) Introduction In: Harrison W, Norcross JJ, Pore NA, Stanley EM (eds) Circulation of Shelf Waters off the Chesapeake Bight. Prof Pap 3. US Dept Comm, Washington, DC

O'Conner NJ (1991) Flexibility in timing of the metamorphic molt by fiddler crab megalopae Uca pugilator Mar Ecol Prog Ser 68:243-247

Olmi EJ III (1994) Vertical migration of blue crab Callinectes sapidus megalopae: implications for transport in estuaries Mar Ecol Prog Ser 113:39-54

Orth RJ, van Montfrans J (1987) Utilization of a seagrass meadow and tidal marsh creek by blue crabs Callinectes sapidus. I. Seasonal and annual variations in abundance with emphasis on post-settlement juveniles. Mar Ecol Prog Ser 41:283-294

Pechenik JA (1990) Delayed metamorphosis by larvae of benthic marine invertebrates: Does it occur? Is there a price to pay? Ophelia 32(1-2):63-94

Possingham HP, Roughgarden J (1990) Spatial population dynamics of a marine organism with a complex lifecycle Ecology 71(3):973-985

Potvin C, Roff D (1993) Distribution-free and robust statistical methods: viable alternatives to parametric statistics. Ecology 74(6): 1617-1628

Roughgarden J, Gaines S, Possingham H (1988) Recruitment dynamics in complex lifecycles. Science 241:1460-1466

Sandifer PA (1975) The role of pelagic larvae in recruitment to populations of adult decapod crustaceans in the York River Estuary and adjacent lower Chesapeake Bay. Virginia. Estuar coast Mar Sci 3:269-279

Sogard SM, Able KW (1991) A comparison of eelgrass, sealettuce macroalgae, and marsh creeks as habitats for epibenthic fishes and decapods. Estuar coast Shelf Sci 33: $501-519$

Stevenson JR (1985) Dynamics of the integument. In: Bliss DE (ed) The biology of Crustacea, Vol 9, Integument, pigments, and hormonal processes. Academic Press, New York, p 1-42

Sulkin SD, van Heukelem W, Kelly P, van Heukelem L (1980) The behavioral basis of larval recruitment in the crab Callinectes sapidus Rathbun: a laboratory investigation of ontogenetic changes in geotaxis and barokinesis. Biol Bull 159:402-417

Williams GB (1964) The effects of Fucus serratus in promoting settlement of larvae of Spirorbis borealis (polychaeta). $\mathrm{J}$ mar biol Ass UK 44:397-414

Wilson KA, Able KW, Heck KL Jr (1990) Predation rates on juvenile blue crabs in estuarine nursery habitats: evidence for the importance of macroalgae (Ulva lactuca). Mar Ecol Prog Ser 58:243-251

Wolcott DL, De Vries MC (1994) Offshore megalopae of Callinectes sapidus: depth of collection, molt stage and response to estuarine cues. Mar Ecol Prog Ser 109:157-163

Manuscript first received: December 15, 1994

Revised version accepted: June 19, 1995 